\title{
Developing a Studio Model Computer Curriculum for First-Year Undergrad- uate Students
}

\section{Prof. Thomas E. Mertz, Kansas State University - Polytechnic Campus}

Thomas Mertz is an associate professor at Kansas State University, Polytechnic Campus, in the School of Integrated Studies. He received his M.S. in Computer Science from the University of Kansas in 1981 and subsequently attended the Ph.D. program at Temple University. He has taught computer science since 1977 as well as working as an independent software developer for a variety of companies. He is currently the program option coordinator for the computer systems, web development and digital media technology programs.

\section{Dr. William E. Genereux, Kansas State University - Polytechnic Campus}

William Genereux is a Professor of Computer \& Digital Media Technology at Kansas State University Polytechnic Campus. His research interests are in media literacy and the educational use of digital media technology. He has been working with computers and technology for the past 30 years.

\section{Prof. Troy Harding, Kansas State University - Polytechnic Campus}

Professor Computer Systems Technology Kansas State University - Polytechnic Campus

\section{Prof. Tim Bower, Kansas State University - Polytechnic Campus Katrina M Lewis}

Katrina Lewis received her Bachelor of Interior Architecture in 1998 and Master of Regional and Community Planning in 2001 from Kansas State University. She has taught design studios at the college level since 1998: at Kansas State University in the Department of Interior Architecture and Product Design for over fifteen years, at Chongqing Jinazhu University in the People's Republic of China for one year, in Afghanistan at Kabul University for two summers, and in Bangladesh at the Asian University for Women for one year.

Lewis' scholarly interests include: teaching methodology, especially with beginning design students; international educational experiences, cultural exchanges, and study abroad; and the intersection between design and social justice. She received the honor of being selected as a Rotary Peace Fellow for professional studies in peace and conflict resolution at Chulalongkorn University, Bangkok, Thailand in Summer 2012. The Fellowship shaped Lewis' desire to explore a stronger understanding between design and peace professionals and higher education.

In 2014, Lewis was awarded tenure and promotion to Associate Professor in the Department of Interior Architecture and Product Design. She has taught in the College's first-year Environmental Design Program since 2001, and currently serves as the College of Architecture, Planning and Design Environmental Design Studies Program First Year Studio Coordinator. In addition, Katrina teaches a contemporary design seminar for Interior Architecture and Product Design. Her creative outlets include travel, reading, fiber arts, and painting.

\section{Prof. Michael Lee Oetken, Kansas State University}

As an Assistant Professor for Kansas State University, I teach courses in the areas of web design, graphic design, digital media design and web development. My areas of expertise are graphic design, HTML, CSS, typography, branding, motion graphics, video production and digital media design. My previous positions in industry as Creative Director, Art Director and Assistant Director of Marketing have garnered an abundant amount of experience and knowledge that I can now pass down to my students through teaching and mentorship. 


\title{
Developing a Studio Model Computer Curriculum for First Year Undergraduate Students
}

\begin{abstract}
This paper describes what was learned while implementing a reinvented undergraduate computer technology curriculum during the first two years of its rollout. The paper includes the activities of the freshman cohorts of computer students who were the first to experience the curriculum redesign.

Perhaps the biggest paradigm shift in the new curriculum was the adoption of the studio model of instruction. Borrowed from other traditions such as art and architecture, the studio provides a hands-on approach to learning that is ideal for computing students; particularly for the large percentage of students who attend our school while already working full time or returning from military service. The first years of using a new approach to teaching always have unique challenges. The computer faculty made decisions about what was important to address in the first year of the curriculum, and what projects to use to keep students engaged in and excited about the field of computing. Since the studio model radically departs from the single instructor classroom lecture model, multiple professors were utilized in the same freshman studio course, each bringing in their own unique areas of expertise.
\end{abstract}

Along with the studio model, electronic portfolios were implemented for the assessment of student learning, as a benchmark that students must pass to advance to the upper-class courses, and for professional presentation to potential employers and clients. The benefits and challenges that were experienced during the first two years of using freshman studios will be discussed as well as what was learned from our assessment efforts.

\section{Background}

Starting in the fall 2016 semester, the computer faculty implemented a revised four-year computer-technology curriculum using a studio course model [1]. Studio courses emphasize a projects and problems-based format as opposed to a traditional academic lecture format.

Around 53\% of students currently enrolled in the computer-technology degree begin their first year of college at age 22 or above, and about $27 \%$ of the enrolled computer students are military veterans. Therefore, many of the students seeking the computer degree are returning to an academic environment from a prior work experience in industry or service in the armed forces.

The new curriculum provides a core foundation in programming, networking, web technologies, database systems and visual design taught by five faculty members with diverse backgrounds and expertise in these areas. Additionally, one of the five faculty members is a military veteran who received a service school education and on-the-job training in advanced electronics and computer systems.

The requirements in the first two years of this revised bachelor's degree curriculum are the same as those of the two-year associate degree in web technology. As a result, all students pursuing the 
bachelor's degree in computer systems also complete the requirements for the web associate degree. The associate degree provides students with the core computer systems foundation using web technology projects and assignments. Thus, students gain a common depth of knowledge with a web emphasis that might otherwise be hard to achieve in classes using other types of computer technologies.

Students seeking only the associate degree are qualified to work in many entry-level webdeveloper jobs [2]. Students seeking the bachelor's degree have the foundation of web technology while continuing to build depth and add breadth as they move through the more advanced classes of the computer-technology program.

A major innovation in the new curriculum is the inclusion of studio courses, which are common in design-oriented fields, such as art and architecture [3], [4]. Similar in style and format to the flipped classroom [5], studios are now being used in science, technology, and engineering areas, as well [6]-[8]. During the freshman and sophomore years, the studio courses are one-credit hour offerings that focus on the students completing projects.

While the goals associated with adding the studio courses are intended to benefit all students, some of these goals are of particular benefit to the older students, including military veterans. Although some new content is taught, these courses are "content light"; the main purpose is for students to apply concepts learned in the other courses taken during the same semester. When we conceived of the studio courses, the intended aims were:

- For faculty to help students connect the dots between the various content courses that students take during the semester and help them see how their learning fits into a broader perspective. The hope was that these connections between courses and their relation to the students' career fields would result in a transformative learning experience [9].

- For computer students to form a cohort of peer learners early in their academic career. Many studies have shown that students who belong to a community of learners tend to be more engaged and are more likely to be successful in the program [10], [11]. Because military veteran students tend to seek out and associate with other veterans, creating cohorts of students with broader demographics is of particular benefit for those students transitioning from military service [12].

- For computer students to be introduced to team building and project-management skills early in their academic careers. One struggle students have had in the capstone course was an inability to handle large, team-based projects, despite having the technical knowledge to solve the problem. The hope was that, with an earlier introduction to these skills, and connecting earlier on with students who possess leadership skills like those coming from the military, students would be more comfortable in the capstone courses.

- To provide a mechanism that requires students to work on keeping their portfolios up-todate.

The second innovation of the new curriculum is the portfolio requirement, in which the student demonstrates that he or she has attained the student learning outcomes (SLOs) of the program. 
For their portfolios, students are required to:

- Showcase their strongest work from a variety of classes, both in and outside of their major.

- Discuss the thought and effort that went into creating the work shown.

- Include written reflections that discuss the challenges faced, strengths and weaknesses, and what was learned from creating the work.

Pedagogical advantages of portfolios have been discussed in the literature. The mere act of reflecting on learning has been shown to assist students to solidify concepts [9]. "When students build their e-portfolios, they also enact a shift from being a consumer to being a producer of their own education. They become learners with agency [13]." Beyond that, the portfolio provides data for assessment of the program's SLOs and demonstrates student abilities to potential employers [14].

\section{Freshman Studio Year 1}

Tables 1 and 2 show how the studio experience was implemented so as to integrate the material taught in the traditional "content" courses. Table 1 shows the freshman courses with content courses required by the major in regular type, the studio courses in boldface type and required general-education courses in italics. Table 2 shows a sample of the SLOs from the fall content courses and how they were integrated into the studio.

\begin{tabular}{|c|c|}
\hline Freshman Fall & Freshman Spring \\
\hline $\begin{array}{l}\text { CMST } 103 \text { Computing Principles............ } 3 \text { cr. } \\
\text { CMST } 135 \text { Web Fundamentals...............3 } \\
\text { CMST } 183 \text { Comp1 Sys Studio I ........... } 1 \\
\text { MATH } 100 \text { College Algebra ...................3 } \\
\text { ENGL } 100 \text { Composition I .................... }\end{array}$ & $\begin{array}{l}\text { CMST } 185 \text { Comp Sys Studio II ............ } 1 \text { cr. } \\
\text { CMST } 247 \text { Programming I .................... } 3 \\
\text { CMST } 250 \text { Hrdwr \& Ntwrk Fund........... } 3 \\
\text { MATH } 150 \text { Plane Trigonometry ............. } 3 \\
\text { PHILO } 105 \text { Intro to Crit Thinking ........... } 3 \\
\text { Business elective .................................. } 3\end{array}$ \\
\hline
\end{tabular}

Table 1 - Computer Systems Curriculum with Studio Courses

\begin{tabular}{|c|c|c|}
\hline Content Course & Sample SLO & CMST 183 Studio SLOs \\
\hline CMST 103 & $\begin{array}{l}\text { Use an event-dr } \\
\text { interact with a } \mathrm{l}\end{array}$ & \multirow{3}{*}{$\begin{array}{l}\text { - Build a website about the game } \\
\text { "Pong" } \\
\text { - Use HTML5, CSS3, and } \\
\text { responsive design } \\
\text { - Articles must describe the history } \\
\text { and workings of the game } \\
\text { - Include the ability for the user to } \\
\text { play pong }\end{array}$} \\
\hline CMST 135 & $\begin{array}{l}\text { Create and format a web page using } \\
\text { HTML and CSS }\end{array}$ & \\
\hline ENGL 100 & $\begin{array}{l}\text { Produce focused papers that have a } \\
\text { consistent purpose and significance }\end{array}$ & \\
\hline
\end{tabular}

Table 2 - Sample of Integration of Fall Content Courses with Fall Studio 


\section{Year 1 Evaluated}

In this first year of implementation of the freshman fall studio, class time was devoted primarily to working on the project. Each student was allowed to choose the subject matter for his/her project so long as it adhered to a list of required features. Each student individually completed the project, which was graded by the studio instructor using a rubric developed by the faculty. Additionally, the students presented their projects to a group of computer and non-computer faculty members, who evaluated the presentation and the design aspects of the project using a common rubric. Table 3 shows the results of the evaluations; there were five students although no veterans participated in the cohort during that semester.

\begin{tabular}{|c|c|c|}
\hline Student & Project Score & Presentation Score \\
\hline 1 & $96.3 \%$ & $94.3 \%$ \\
\hline 2 & 93.8 & 84.3 \\
\hline 3 & 86.3 & 86.4 \\
\hline 4 & 77.5 & 87.7 \\
\hline 5 & 61.3 & 88.3 \\
\hline
\end{tabular}

Table 3 - Fall 2016 Studio I Project and Presentation Scores

(No veteran students were in this cohort)

Each student wrote a reflection paper about his or her experience. Following are some general observations that students made in their reflection papers:

- They enjoyed the depth of learning beyond the other courses that the project allowed.

- They were forced to learn technologies that they would not have learned without the studio class.

- They gained a better understanding of the concepts in the other classes by applying them to the project.

- They enjoyed the structuring of the studio and a project that was outside of the scope of their other classes.

- They felt there was not enough material in the studio course to fill up the class time.

- They had trouble manipulating images on the web and felt that more instruction was needed.

Students were also given the opportunity to provide feedback about the studio course format on the teacher evaluation at the end of the semester. When asked, "Name at least one thing that you would like changed in the studio class," some of the comments included:

- A little more group work as a class to serve as refreshers when the class is only happening one day a week.

- Some of the projects seemed too complex, with not a lot of time to work in class.

- I feel like the studio class could use more projects focused on digital media.

- I would like to add a section of optional assignments for us, the students to gauge and test our abilities. 


\section{Freshman Studio Year 2}

One advantage of the new curriculum's studios is that they allow a much more timely application of the academic assessment cycle. Instead of evaluating seniors based on program assessments, we can evaluate each cohort at the end of each academic year and implement improvements for the next cohort. For year 2, we responded to the student feedback by adding additional material to the studios, including:

- Digital graphics creation and editing using Adobe ${ }^{\circledR}$ Photoshop $^{\circledR}$ and Adobe Illustrator ${ }^{\circledR}$. The students learned how to apply these skills to web-design projects by creating and editing multiple web banner graphics.

- Basic video editing and post-production techniques using Adobe Premiere ${ }^{\circledR}$ and Adobe Media Encoder. The students edited a basic video and encoded it for multiple webdeployment platforms.

- Animated graphics and movies using Adobe After Effects ${ }^{\circledR}$. The students created simple animations.

The team-teaching paradigm allowed us to do this because content was taught by different faculty members with different areas of expertise. We consider this content as "value-added," because students learn something they can use in their projects without having to take additional courses. Prior to the new curriculum, only students studying digital media would have experienced these technologies. With the new studio course, all computer students are exposed to them, regardless of their ultimate career interests.

\section{Year 2 Evaluated}

In year 2 of the studio class, no change was made to the course's project requirements. Projects were evaluated using the same rubrics and methods described for year 1. Four of the twelve students were military veterans.

\begin{tabular}{c|c|c}
\hline Student & Project Score & Presentation Score \\
\hline$* 1$ & $97.8 \%$ & $96.0 \%$ \\
\hline$* 2$ & 93.3 & 92.9 \\
\hline 3 & 92.8 & 76.8 \\
\hline 4 & 90.0 & 94.0 \\
\hline 5 & 85.6 & 92.0 \\
\hline 6 & 85.0 & 94.0 \\
\hline 7 & 83.8 & 98.0 \\
\hline 8 & 82.2 & 74.8 \\
\hline$* 9$ & 80.6 & 76.8 \\
\hline 10 & 76.7 & 87.3 \\
\hline 11 & 73.9 & 82.0 \\
\hline 12 & 67.0 & 60.0 \\
\hline
\end{tabular}

Table 4 - Fall 2017 Studio I Project and Presentation Scores

(* Indicates a military veteran) 


\section{Veteran Voices from Year 2}

While there were no veteran students in the first cohort starting the new curriculum in the Fall 2016 semester, there were four veteran students in the second year's cohort of the Fall 2017 semester. Three of these four veteran students sat down with a computer faculty member, who is also a military veteran, to talk about their experience in the freshman studio course. The different students are marked with a VS1, VS2 and VS3, distinguishing each of the three different veteran student voices. Some of their comments from this unstructured interview are included below:

- VS1. "I find it very challenging to go to a traditional school because we come out of high school and we go into the military where the training is very applied. They teach you what you need to know to do your job and they teach it very well. They don't throw on extra stuff. Then you come to university where they start throwing in things on my schedule. I'm like why do I need this? ... It's a whole different approach to education that we've had from [military] training so this [studio model] is bringing you much closer to that method of education."

- VS2. "I definitely like the hands-on in the studio. Being able to work with some of the different software programs. Some of the different projects."

- VS1. "The studio is a lot like a lab, but you're bringing in what you've learned in all of your classes together. You've taken everything that you've spent your time and money on learning and you're putting it into an actual project that means something so it all makes sense in why you are taking the classes. It all comes together."

- VS2. "I definitely like the one-on-one in the studio. Not just one-on-one because sometimes we had multiple professors that would be in there on the same day. You might have had two or three professors there that day. If somebody was tied up with another student you could still have a professor, you could get help."

- VS1. "In my first two semesters, I didn't talk to anybody. I didn't talk to anybody my first year."

- VS2. "We are good friends now but we didn't even speak to each other. I barely looked over in his direction."

- VS1. "I was very, very, very introverted when I first came here."

- VS2. "I don't know where it actually started from. I think we started showing each other things we were working on in class and built upon that. We started finding out that we are both in similar degree programs and we shared an experience; we both served in Iraq. I think that's where we hit it off. The first studio class probably brought us together."

- VS2. "We're starting to realize that hey, we're going to be in Studio I together, we will be in Studio II together, and in these other classes together-"

- VS3. "The studio kind of rallied all of us together. We could talk about, hey I'm taking statistics, I'm in chemistry etc."

- VS2. "When you start working on these big projects, you start seeing the same people in all of these different classes. We are even taking calculus together. For us it's easy to collaborate on these other classes, even Gen Ed classes, because we're together throughout the curriculum."

- VS3. "There's always some student who always sits here and I'm like, hey how are you doing?" 


\section{The Status of Electronic Portfolios}

The two main problems initiating electronic portfolios were:

- Finding a platform that allowed the students to show both executable and non-executable work.

- Getting the students to write true reflections rather than project summaries that had no introspection on what had been gained from doing the work.

To implement the portfolio requirement, and address these problems, we have:

- Developed specific requirements for portfolio content and for how to write reflections.

- Chosen a combination platform for portfolios. Students host executable work on GitHub and non-executable work on Canvas, which is the Learning Management System used at our college. Canvas is a good tool because the students can easily move assignments from the assignment drop boxes into the portfolio.

- Incorporated into the freshman studio two digital-media design modules covering introductory terminology and techniques that students can apply to their portfolios.

- Incorporated into later studios opportunities for the students to work on and get feedback on their portfolios.

\section{Discussion}

Based on the data above, we believe the one-credit studio model has been successful, especially in fulfilling the first two of our aims: having the students connect the dots between the various course content and having the students bond into cohorts.

The studio approach seems particularly suited to the non-traditional students who are military veterans, as indicated by their performance and feedback from the unstructured interviews. One student stated that, as they saw the same students in their other classes, they became more comfortable with collaborations and teamwork. The veterans also felt that the studio model of teaching and learning was more familiar to them than traditional college courses.

Regarding the faculty, the faculty members teaching the one-credit hour studios had to create a learning environment in which they weren't the content experts in all the material being taught. This gave them an uncomfortable feeling in that answers and outcomes to all student questions and problems could not be known in advance. This mirrors the real world in an authentic way, but caused concern for faculty uncomfortable with forging ahead into the unknown.

Team-teaching presents its own set of problems. For example, how should a team-taught course by two or more faculty members weigh into traditional calculations of teaching load? How can faculty members model effective and cooperative teamwork to the students? Differences in personality and philosophy play a part in how successful team teaching can be. Overall, the faculty have been positive about the change. Staying flexible and realizing that creating a realworld but sometimes messy learning environment is beneficial to students. Students enrolled in 
the new curriculum have benefited by learning a broad range of topics and skills early on in the studio course during the very first semester.

Media computing has been discussed as a way to improve student engagement and retention in the very first computer course [15], [16]. Our studio courses introduce various forms of digital media, along with the core computing topics of programming, networking, databases, and website development. While we are still very early in the implementation of this curriculum, the new approach appears to be achieving the desired effects with the students.

In developing this new approach to teaching the computer technology program, the faculty enjoyed strong support and encouragement of the institution's administrative team. Having support of the institution and its leadership is vital to the success of using innovative teaching methods such as team-teaching [17].

\section{Future Plans}

Building on what we have learned during the two years of the new curriculum and the changes we have made to the freshman studios, we are confident that we are making innovative improvements to our students' education in web design and computer technology. We are pleased that we appear to be meeting the educational needs of our military veteran students.

Our next goals are to:

- Place the assessment instruments for the freshman courses onto Canvas, so as to more easily compile assessment data.

- Continue gathering student feedback for continual program improvement.

- Implement the studio-course paradigm for the sophomore year-an effort that we have already begun.

- Fully implement the portfolio initiative.

\section{References}

[1] Harding, T., Mertz, T. E., Genereux, W. E., Guzek, S. A., Bower, T. (2017). Reinventing a computer technology curriculum to meet the needs of students and future employers. Proceedings of the 2017 American Society for Engineering Education Annual Conference \& Exposition, Columbus, Ohio. Retrieved from https://peer.asee.org/28790.

[2] Bureau of Labor Statistics, U.S. Department of Labor (2018). Occupational Outlook Handbook, Web Developers. Retrieved from https://www.bls.gov/ooh/computer-andinformation-technology/web-developers.htm.

[3] Koo, T. S. (2012). Integrating design disciplines: Understanding the potential for and factors affecting the success of interdisciplinary design education for architecture and landscape architecture (Doctoral Dissertation). Retrieved from ProQuest Dissertations \& 
Theses Global. (Order No. 3520938).

[4] Dutton, T. A. (1987). Design and studio pedagogy. Journal of Architectural Education, 41(1), 16-25.

[5] Bishop, J. \& Verleger, M., (2013). The flipped classroom: A survey of the research. Proceedings of the 2013 American Society for Engineering Education Annual Conference \& Exposition, Atlanta, GA. Retrieved from https://peer.asee.org/22585.

[6] Habash, R. W. Y., Suurtamm, C., \& Necsulescu, D. (2011). Mechatronics learning studio: From "play and learn" to industry-inspired green energy applications. IEEE Transactions on Education, 54(4), 667-674.

[7] Hill, J. (2007). Incorporating studio format into an introductory microprocessor course. Proceedings of the 2007 American Society for Engineering Education Annual Conference \& Exposition, Honolulu, HI. Retrieved from https://peer.asee.org/1621.

[8] Powell, H. C., Brandt-Pearce, M., \& Williams, R. D., Weikle, R. M., \& Harriott, L. R. (2016). Incorporating studio techniques with a breadth-first approach in electrical and computer engineering education. Proceedings of the 2016 American Society for Engineering Education Annual Conference \& Exposition, New Orleans, LA. Retrieved from https://peer.asee.org/25661.

[9] Stansberry, S. L., \& Kymes, A. D. (2007). Transformative learning through "teaching with technology" electronic portfolios. Journal of Adolescent \& Adult Literacy, 50(6), 488-496.

[10] Beachboard, M. R., Beachboard, J. C., Li, W., \& Adkison, S. R. (2011). Cohorts and relatedness: Self-determination theory as an explanation of how learning communities affect educational outcomes. Research in Higher Education, 52(8), 853-874.

[11] Brownell, M. T., Yeager, E. A., Sindelar, P. T., \& Riley, T. (2004). Teacher learning cohorts: A vehicle for supporting beginning teachers. Teacher Education and Special Education: The Journal of the Teacher Education Division of the Council for Exceptional Children, 27(2), 174-189.

[12] Schiavone, V. \& Gentry, D. (2014). "Veteran-Students in Transition at a Midwestern University," Journal of Continuing Higher Education, (62)1, 29-38.

[13] Hubert, D., Pickavance, J., \& Hyberger, A. (2015). Reflective e-portfolios: one HIP to rule them all? Peer Review, 17(4), 15+. Retrieved from http://link.galegroup.com/apps/doc/A452288433/EAIM?u=ksu\&sid=EAIM\&xid=c1 c350 84 
[14] Fahey, K., Lawrence, J., \& Paratore, J. (2007). Using electronic portfolios to make learning public. Journal of Adolescent \& Adult Literacy, 50(6), 460-471.

[15] Guzdial, M. (2003). A media computation course for non-majors. Proceedings of the 8th annual conference on Innovation and technology in computer science education, (35)3, 104-108.

[16] Simon, B., Kinnunen, P., Porter, L. \& Zazkis, D. (2010). Experience report: CS1 for majors with media computation. Proceedings of the fifteenth annual conference on Innovation and technology in computer science education. 214-218.

[17] Letterman, M. \& Dugan, K. (2004). Team teaching a cross-disciplinary honors course: Preparation and development. College Teaching, 52(2), 76-79. Retrieved from https://poorvucenter.yale.edu/sites/default/files/basic-page-supplementary-materialsfiles/team_teaching.pdf 